\title{
RETENTION OF SOME FLAVONES AND FLAVANONES IN FLOUR, GRAIN AND BRAN OF SORGHUM DURING STORAGE
}

\author{
VALÉRIA APARECIDA VIEIRA QUEIROZ ${ }^{1}$, KÊNIA GRASIELLE DE OLIVEIRA ${ }^{2}$, \\ CAROLINE LIBOREIRO PAIVA ${ }^{3}$, LANAMAR DE ALMEIDA CARLOS ${ }^{2}$, \\ CÍCERO BESERRA DE MENEZES ${ }^{1}$, FREDERICO AUGUSTO RIBEIRO DE BARROS ${ }^{4}$, \\ HELENA MARIA PINHEIRO-SANT' ANA $^{5}$ and PAMELLA CRISTINE ANUNCIAÇÃO ${ }^{5}$
}

\begin{abstract}
${ }^{1}$ Empresa Brasileira de Pesquisa Agropecuária - Embrapa, Embrapa Milho e Sorgo, Rodovia MG 424, km 65, Caixa Postal 151, Sete Lagoas, Minas Gerais, Brasil, CEP 35701-970.Email: valeria.vieira@embrapa.br, cicero.menezes@embrapa.br ${ }^{2}$ Laboratório de Ciência e Tecnologia de Alimentos, Universidade Federal de São João del-Rei, Rodovia MG 424-Km 45, Caixa postal, 56, Sete Lagoas, Minas Gerais, Brasil, CEP 35701-970. Email: keniagrasi@yahoo.com.br,lanamar@ufsj.edu.br ${ }^{3}$ Instituto de Ciências Agrárias, Universidade Federal de Minas Gerais, Av. Universitária, 1000, Montes Claros, Minas Gerais, Brasil, CEP 39404-547. Email: carolinepaiva7@gmail.com

${ }^{4}$ Departamento de Tecnologia de Alimentos, Universidade Federal de Viçosa, Avenida PH Holfs, s / $n$ Viçosa, Minas Gerais, Brasil, CEP: 36570-000.Email: fredbarros@ufv.br

${ }^{5}$ Departamento de Nutrição e Saúde, Universidade Federal de Viçosa, Avenida PH Holfs, s / n Viçosa, Minas Gerais, Brasil, CEP36570-000.Email: helena.santana@ufv.br,nutripamella@gmail.com
\end{abstract}

Revista Brasileira de Milho e Sorgo, v.17, n.3, p. 522-534, 2018

\begin{abstract}
Sorghum is associated with several functional benefits because it contains high levels of phenolic compounds, such as the flavonoids, flavones and flavanones. However, these compounds are sensitive to the period and conditions of storage. Thus, this work aimed to evaluate luteolin, apigenin, naringenin and eriodictyol retention in the sorghum genotypes SC319 (flour and grain) and TX430 (flour and bran) stored for 180 days at 4,25 and $40{ }^{\circ} \mathrm{C}$. These compounds were quantified by a high-performance liquid chromatograph equipped with a diode array detector. There was effect of the storage time, which favored the flavone and flavanone reduction in the evaluated genotypes. The storage temperature influenced the flavones more than the flavanone contents. The retentions ranged from 70.27 to $88.72 \%$ for luteolin, 69.04 to $99.15 \%$ for apigenin, 56.92 to $88.51 \%$ for naringenin and from 77.10 to $93.42 \%$ for eriodictyol at the three temperatures at the end of 180 days. Although flavones and flavanones were better preserved at $4{ }^{\circ} \mathrm{C}$ (about $88 \%$ of retention), at room temperature $\left(25^{\circ} \mathrm{C}\right)$ flavones and flavanones retentions were at least $77 \%$ and $85 \%$ after 180 days.
\end{abstract}

Keywords: Sorghum bicolor (L.) Moench, storage losses, bioactive compounds, flavonoids retention.

\section{RETENÇÃO DE ALGUMAS FLAVONAS E FLAVANONAS EM FARINHA DE SORGO, GRÃO E FARELO DURANTE O ARMAZENAMENTO}

RESUMO - O sorgo está associado a várias propriedades funcionais pelo fato de conter altos níveis de compostos fenólicos, como flavonoides, flavonas e flavanonas. No entanto, estes compostos são sensíveis ao período e condições de armazenamento. Assim, este trabalho teve como objetivo avaliar a retenção de luteolina, apigenina, naringenina e eriodictilol nos genótipos de sorgo SC319 (farinha e grão) e TX430 (farinha e farelo) armazenados por 180 dias a 4, 25 e $40{ }^{\circ} \mathrm{C}$. Estes compostos foram quantificados por cromatografia líquida de alto desempenho acoplada a detector de arranjo de diodos. Houve efeito do tempo de armazenamento, que favoreceu a redução de flavona e flavanona nos genótipos avaliados. A temperatura de armazenamento influenciou as flavonas mais do que o conteúdo de flavanona. As retenções variaram de 70,27 a 88,72\% para luteolina, 69,04 a $99,15 \%$ para apigenina, 56,92 a $88,51 \%$ para naringenina e de 77,10 a $93,42 \%$ para eriodictilol nas três temperaturas no final de 180 dias. Embora as flavonas e flavanonas tenham sido melhor conservadas a $4{ }^{\circ} \mathrm{C}$ (cerca de $88 \%$ de retenção), em temperatura ambiente $\left(25^{\circ} \mathrm{C}\right)$, as retenções de flavonas e flavanonas foram pelo menos $77 \%$ e $85 \%$ após 180 dias.

Palavras-chave: Sorghum bicolor (L.) Moench, perdas durante o armazenamento, compostos bioativos, retenção de flavonoides. 
Flavonoids are plant secondary metabolites and the largest group of naturally occurring plant phenolic compounds. Depending on the oxidation degree of the central pyran ring, they can be subdivided into the following classes: flavones, flavonols, flavanones, flavanols, isoflavones and anthocyanidins (Balasundram et al., 2006). In general, the beneficial effects of a diet rich in these compounds is related to their antioxidant, anti-inflammatory, anticarcinogenic and cardio protective capacities (Awika \& Rooney, 2004; Awika et al., 2005; Balasundram et al., 2006; Moraes et al., 2012). Specifically, the health benefits of flavones have been related to antioxidant, antiproliferative, anti-tumor, anti-microbial, estrogenic, acetyl cholinesterase, anti-inflammatory activities (Verma \& Pratap, 2012; Singh et al., 2014) and neuro-protective capacity (Ravishankar et al., 2016). In relation to flavanones, research has demonstrated the antioxidant properties (Khan \& Dangles, 2014).

Sorghum (Sorghum bicolor (L) Moech) is a cereal that stands out due to its nutritional and functional benefits. This grain provides mainly carbohydrates, proteins, fibers, vitamins (especially B complex) (Queiroz et al., 2015) and minerals (magnesium and zinc) (Paiva et al., 2017). In addition, it contains phenolic compounds relevant to human health, such as phenolic acids, condensed tannins, flavones, flavanones and anthocyanins (Dykes \& Rooney, 2006). According to in vitro and in vivo preliminary studies, these sorghum compounds are related to the prevention of chronic diseases, including diabetes, cancer, hypertension, obesity and cardiovascular disease (Awika \& Rooney, 2004; Cardoso et al., 2014; Moraes et al., 2012).

Among the flavonoids, the anthocyanins, especially the 3-deoxyanthocyanins, comprise the most studied class of flavonoids in sorghum grain (Dykes \& Rooney, 2006) and are concentrated in the bran (Awika et al., 2005; Dykes \& Rooney, 2006; Moraes et al., 2015). Few works in the literature are available in relation to flavones and flavanones in sorghum. The flavones apigenin and luteolin have already been found in brown, red, yellow (Cardoso et al., 2015; Dykes et al., 2011), white and black pericarp sorghums (Yang et al., 2012). The flavanones naringenin and eriodictyol have also been found in sorghum (Dykes et al., 2011; Yang et al., 2012; Cardoso et al., 2015). According to Cardoso et al. (2015) and Dykes et al. (2011), the yellow pericarp sorghums are more abundant in flavones and flavanones. However, flavonoids are sensitive to the physicochemical environment (Ioannou et al., 2012). Thus, the period and conditions of storage may influence their contents. Therefore, understanding the effects of storage period and temperature on the levels of sorghum phenolic compounds are important to preserve their properties during shelf life. Besides, information has not been found in the literature regarding the stability and/or behavior of the flavones and flavanones during storage. Thus, the objective of this study was to evaluate the flavone and flavanone retention in flour, grain and bran of sorghum during storage at different temperatures.

\section{Material and Methods}

The standards of luteolin, apigenin, naringenin and eriodictyol were obtained from Sigma-Aldrich (St. Louis, MO, USA). For the extraction and analyses, analytic grade reagents purchased from Vetec (São Paulo) were used. High performance liquid chromatography (HPLC) grade reagents (methanol, ethyl acetate, acetone, acetonitrile, hexane, isopropyl alcohol, acetic acid and formic acid) were purchased from Tedia (São Paulo). 


\subsection{Sorghum samples}

Two sorghum genotypes were used: the genotype SC319 (grain and flour), with brown pericarp and pigmented testa (Cardoso et al., 2015) and the genotype TX430 (bran and flour), with black pericarp and without pigmented testa (Dykes et al., 2009).

The genotype SC319 was selected among 100 genotypes of a panel with high genetic variability, due to its high total phenolic contents (unpublished data). This genotype was grown in experimental fields of Embrapa Milho e Sorgo, in Sete Lagoas, Minas Gerais, in 2013. After harvesting, the grains were threshed and stored at $-18{ }^{\circ} \mathrm{C}$ until use. The whole sorghum grains were ground twice in a Hawos mill before storage. The genotype TX430 was supplied by CQL-Cereal Quality Lab., from Texas A\&M University, College Station, TX, USA and was selected due to its high flavonoid content. This sorghum genotype was grown in College Station, TX, in 2013. After harvesting, the grains were milled using a UDY cyclone mill (Model 3010-030, UDY Corporation, Fort Collins, CO). The bran was obtained by decorticating the sorghum grains in a PRL mini-dehuller (Nutama machine Co., Saskatoon, Canada) and separated with a KICE grain cleaner (Model 6DT4-1, KICE Industries Inc., Wichita, KS).

After storage, all samples were ground in a cyclone mill (Marconi, Piracicaba, São Paulo) to obtain a particle size of $0.5 \mathrm{~mm}$ for use in the chemical analysis.

Sorghum genotypes SC319 (grains and flour) and TX430 (flour and bran) were placed in individual polypropylene packages with $10 \mathrm{~g}$ capacity. Subsequently, the packages were placed in paper bags to protect from light and stored in three BOD Refrigerated Incubators (SOLAB 200/334) for a period of 180 days, at three temperatures $\left(4{ }^{\circ} \mathrm{C} \pm\right.$ $2{ }^{\circ} \mathrm{C}, 25{ }^{\circ} \mathrm{C} \pm 2{ }^{\circ} \mathrm{C}$ and $40{ }^{\circ} \mathrm{C} \pm 2{ }^{\circ} \mathrm{C}$. Chemical analyses were performed at 0 (zero, T0), 60 (T60), 120 (T120), and 180 (T180) days of storage. Sorghum grains (from the genotype SC319) remained intact during the storage period and were ground before the analytical procedures.

The levels of flavones (luteolin and apigenin) and flavanones (naringenin and eriodictyol) were analyzed simultaneously in the sorghum samples, according to the method proposed by Yang et al. (2012) and modified by Cardoso et al. (2014). For extraction, $20 \mathrm{~mL}$ of $1 \%$ hydrochloric acid in methanol were added to $1 \mathrm{~g}$ of sample and stirred for $2 \mathrm{~h}$ at 180 rpm. The suspension was then centrifuged (FANEM Excelsa Baby II centrifuge) at $2790 \mathrm{~g}$ for $5 \mathrm{~min}$ and the supernatant collected and its volume made up to $20 \mathrm{ml}$ with acidified methanol. Subsequently, the extract was placed in an amber bottle and stored at $-18 \pm 1{ }^{\circ} \mathrm{C}$ until analysis (Dykes et al., 2009). Flavones and flavanones were quantified by a HPLC system (Shimadzu, SCL 10AT VP, Japan) equipped with diode array detector (DAD) (Shimadzu, SPDM10A, Japan), high-pressure pump (Shimadzu, LC10AT VP, Japan), autosampler with loop of $500 \mu \mathrm{L}$ (Shimadzu, SIL-10AF, Japan), and helium degassing system of the mobile phase (Shimadzu, DGU-2 A, Japan). The chromatographic conditions used for the analysis included a HPLC system, C-18 Kinetex column $(150 \times 4.6 \mathrm{~mm}$ i.d., $5 \mu \mathrm{m})$ fitted with a C-18 guard column (4 mm x $3 \mathrm{~mm}$ ) (Phenomenex, Torrance, CA), column temperature $35^{\circ} \mathrm{C}$, injection volume $15 \mu \mathrm{L}$ and spectrum scan from 200-700 $\mathrm{nm}$. The flavones and flavanones were measured at 340 $\mathrm{nm}$ and $280 \mathrm{~nm}$, respectively (Cardoso et al., 2014).

Flavone and flavanone were identified by comparing of the retention times of the peaks in the 
sample in relation to standards and confirmed by the addition of the suspect compound to the sample, in duplicate. The R2 of the analytical curves ranged from 0.9939 to 0.9992 . The flavones and flavanones concentrations were expressed in $\mu \mathrm{g} / \mathrm{g}$ on dry weight basis.

The apparent retention of the flavones and flavanones, at the end of storage (180 days), was calculated according to the equation:

Retention $(\%)=[$ Content at 180 days $(T 180) \div$ Content at time zero $(T 0)] \times 100$

A completely randomized design in a $2 \times 3 \times 4$ factorial was used for flavones and flavanones ( 2 types of products $\mathrm{x} 3$ temperatures $\mathrm{x} 4$ storage periods). The genotypes were analyzed separately. The data were submitted to analysis of variance (ANOVA) and the means were compared by the Tukey test at 5\% of probability, using SISVAR Software, version 5.6 (UFLA, Lavras, MG).

\section{Results and Discussion}

There was no difference $(\mathrm{p}>0.05)$ in flavone content between flour and grain of the SC319 genotype. However, the difference was significant $(p \leq 0.05)$ between flour and bran of TX430 genotype. The sorghum bran of the TX430 genotype showed approximately 6 times more luteolin and about 3 times more apigenin than the flour (Figure 1 and Figure 2). These results are in accordance with other studies that demonstrated that flavonoids, as other phenolic compounds, are located mainly in the pericarp of the grain (Awika et al., 2005; Dykes \& Rooney, 2006; Dykes et al., 2009, 2011; Moraes et al., 2015).

The contents of the flavones luteolin and apigenin in the SC319 genotype (flour and grain) and TX430 (bran) were influenced by temperature and storage period and by the interaction of the temperatures $\mathrm{x}$ storage periods. The levels of these compounds remained high when stored at $4{ }^{\circ} \mathrm{C}$ compared to 25 and $40{ }^{\circ} \mathrm{C}$ during 180 days. Flavone contents of the TX430 flour were stable for 180 days at the three temperatures. The curves of flavone degradation in sorghum grain, flour and bran, under 4, 25 and $40{ }^{\circ} \mathrm{C}$ showed the same polynomial function (Figure 1 and Figure 2).

In the literature, there is no information about changes in flavone content in cereal during storage under different temperatures. However, in fruits and vegetables these changes have been observed. Some researchers have shown that flavone levels, specifically luteolin and apigenin, from fruits and medicinal leaves had a large decline towards the end of the storage period at $4{ }^{\circ} \mathrm{C}$. This is probably due to the breakdown of the cellular structure and consequent loss of water due to chilling injury (Liu et al., 2010; Kadivec et al., 2013). In orange juice treated with pulsed electric fields and storage under $4{ }^{\circ} \mathrm{C}$, apigenin and luteolin levels remained constant after 180 days (Agcam et al., 2014). At $25^{\circ} \mathrm{C}$, apigenin and luteolin of olive oil remained stable when stored for 300 days (Lozano-Sánchez et al., 2013). A similar result was found in pigeon pea leaves stored during 120 days at the same temperature (Liu et al., 2010). Strawberries stored during 19 weeks at room temperature $\left(20^{\circ} \mathrm{C}\right)$ showed a rapid decrease in luteolin levels, with almost 99\% loss (Kadivec et al., 2013).

According to Hounsome et al. (2009), changes in flavonoid compounds during long-term storage of plants are complex and reflect particular characteristics such as postharvest senescence, previous microorganism attack and harvest cycle.

In the Oliveira et al. (2017) study with sorghum grain and flour during storage, a similar decrease was observed in the levels of other types of flavonoids 

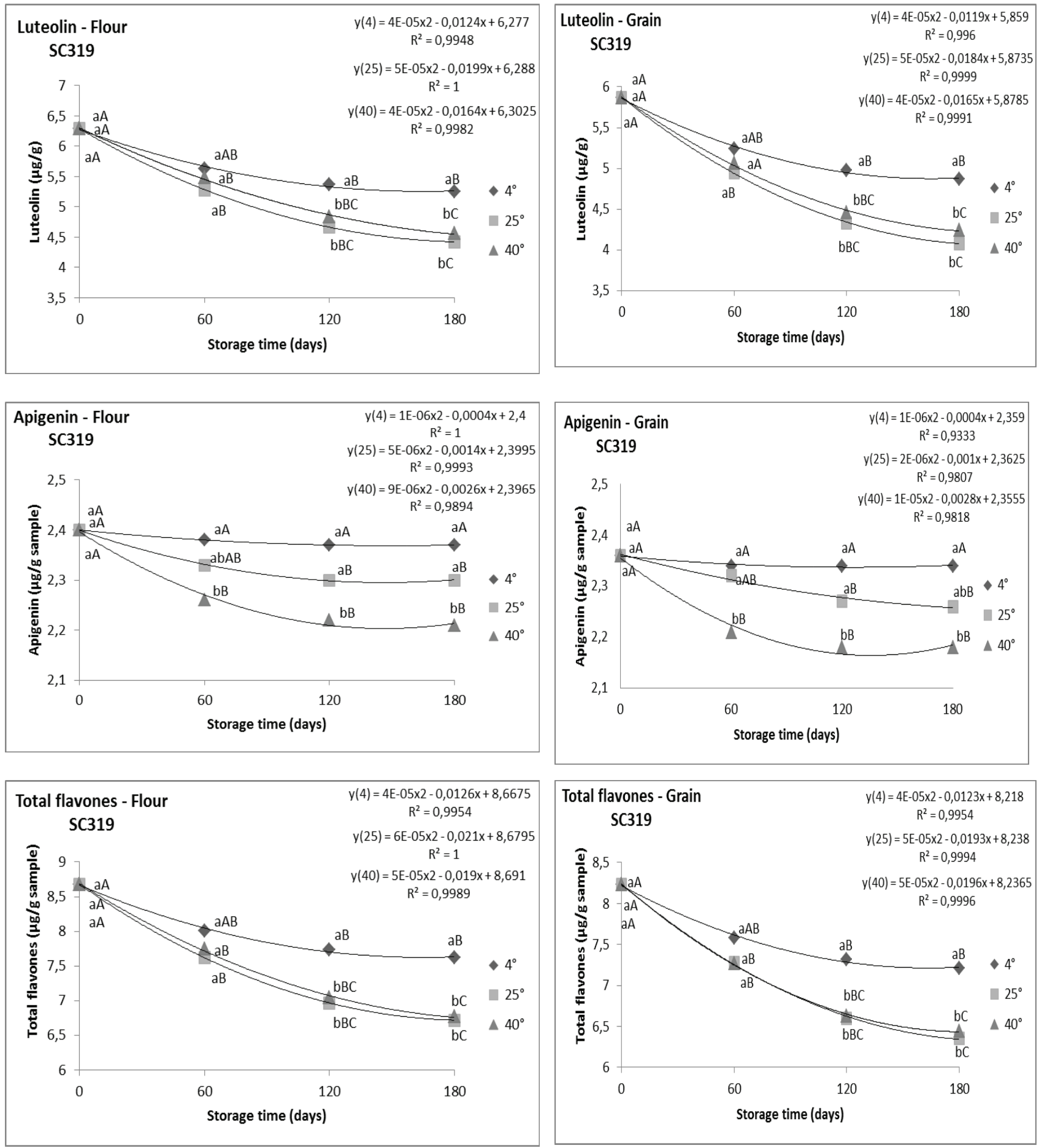

Figure 1. Flavones contents on sorghum genotype SC319 (flour and grain) stored for 180 days under three temperatures $\left(4,25\right.$ and $\left.40{ }^{\circ} \mathrm{C}\right)$. Results are expressed in $\mu \mathrm{g} / \mathrm{g}$ of sample on dry weight basis. Means of three replicates. Means with different lowercase letters among the temperatures and uppercase letters among the times are different by Tukey test ( $\mathrm{p}>0.05)$. 

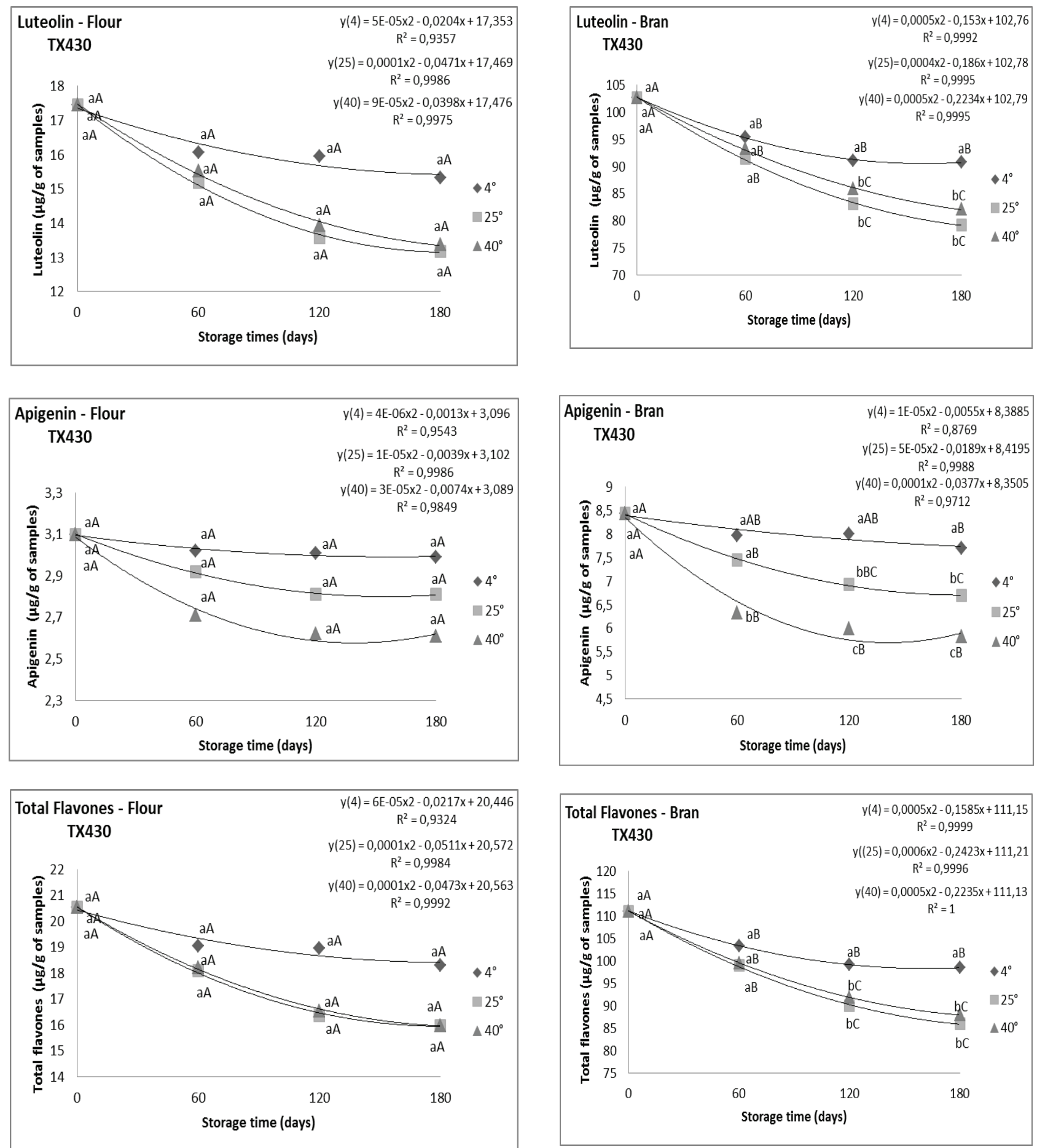

Figure 2. Flavones contents on sorghum genotype TX430 (flour and bran) stored for 180 days under three temperatures $\left(4,25\right.$ and $\left.40^{\circ} \mathrm{C}\right)$. Results are expressed in $\mu \mathrm{g} / \mathrm{g}$ of sample on dry weight basis. Means of three replicates. Means with different lowercase letters among the temperatures and uppercase letters among the times are different by Tukey test $(\mathrm{p}<0.05)$. 
(3-deoxyanthocyanins) during storage under 4, 25 and $40{ }^{\circ} \mathrm{C}$. Sorghum has lower water activity compared to fruits and vegetables, and furthermore, the structure of the grain is able to protect the cells from chilling injury, what could explain the greater stability of flavones during storage under $4{ }^{\circ} \mathrm{C}$.

At $40{ }^{\circ} \mathrm{C}$, there was a decrease in the total flavones in the sorghum grain and flour of the SC319 genotype from the initial to the $60^{\text {th }}$ day of storage and then the contents remained stable until the $120^{\text {th }}$ or $180^{\text {th }}$ day (Figure 1). When comparing the flavone losses at 4 and $25^{\circ} \mathrm{C}$ in the flour and grain of this genotype luteolin showed a tendency to be more sensitive to high temperature than apigenin. Cardoso et al. (2015) also verified this trend regarding the effect of dry heat treatment and conventional oven treatment to sorghum flour. In the same way, Allouche et al. (2007) had verified that luteolin from extra virgin olive oil decreased rapidly with the heating time $\left(180{ }^{\circ} \mathrm{C}\right.$ for $36 \mathrm{~h}$ in a hot air oven), while apigenin showed a slower degradation. The performance of the sum of flavones content was similar to that of luteolin during storage, maybe because the amount of luteolin is about twice as high as apigenin.

Therefore, storage under $4{ }^{\circ} \mathrm{C}$ was more efficient to preserve the luteolin and apigenin contents from grain, flour and bran of sorghum. However, with few exceptions, there was no significant difference in flavone levels between sorghum samples stored under 25 and $40{ }^{\circ} \mathrm{C}$ (Fig. 1 and Fig. 2).

There was no difference $(p>0.05)$ in the flavanone contents between flour and grain of the SC319 genotype. However, the difference was significant between flour and bran of the TX430 genotype. The TX430 bran had flavanone concentrations about 5 to 6 times higher than the flour (Fig. 3 and Fig. 4).
There was no significant $(p>0.05)$ effect of temperature and storage period on the naringenin content on the sorghum flour and grain of the SC319 genotype neither on the flour of TX430 genotype, i.e., the level of this compound remained stable during storage for 180 days (Fig. 3 and Fig. 4). In TX430 bran, at each temperature the naringenin content remained stable until the $120^{\text {th }}$ day (Figure 4). These results indicate that naringenin has a high stability even when stored at $40{ }^{\circ} \mathrm{C}$. The curves of flavanones degradation in sorghum grain, flour and bran had shown the polynomial function at $4{ }^{\circ} \mathrm{C}, 25^{\circ} \mathrm{C}$ and $40{ }^{\circ} \mathrm{C}$, in the same way of flavones. This was similar to behavior of other sorghum flavonoids (Oliveira et al, 2017).

No studies were found in the literature regarding flavanone losses in cereals during storage. The changes of flavanone levels in fruits during storage seem to be different from those observed in sorghum. Naringenin levels of orange juice increased when stored during 180 days at $4{ }^{\circ} \mathrm{C}$ after previous pulsed electric field (PEF) treatments (Agcam et al., 2014). On the other hand, in minimally processed orange the naringenin concentration did not change during 12 days of cold storage at $4{ }^{\circ} \mathrm{C}$ (Plaza et al., 2011).

The effects of temperature, storage time and temperatures $\mathrm{x}$ times interaction on eriodictyol content of SC319 genotype (flour and grain) and TX430 bran (Fig. 3 and Fig. 4) were significant. The level of eridioctyol in the flour of TX430 was not influenced by any of these factors during storage (Fig. 4).

For both genotypes the eridioctyol content was similar at 4 and $25{ }^{\circ} \mathrm{C}$, but reduced considerably at $40{ }^{\circ} \mathrm{C}$. At $4{ }^{\circ} \mathrm{C}$, the level remained stable from the initial to the end of storage, except in the TX430 bran that presented reduced content at the $180^{\text {th }}$ day of storage. The losses of eridioctyol at $25{ }^{\circ} \mathrm{C}$ occurred from the $60^{\text {th }}$ to $120^{\text {th }}$ day and from the beginning of 

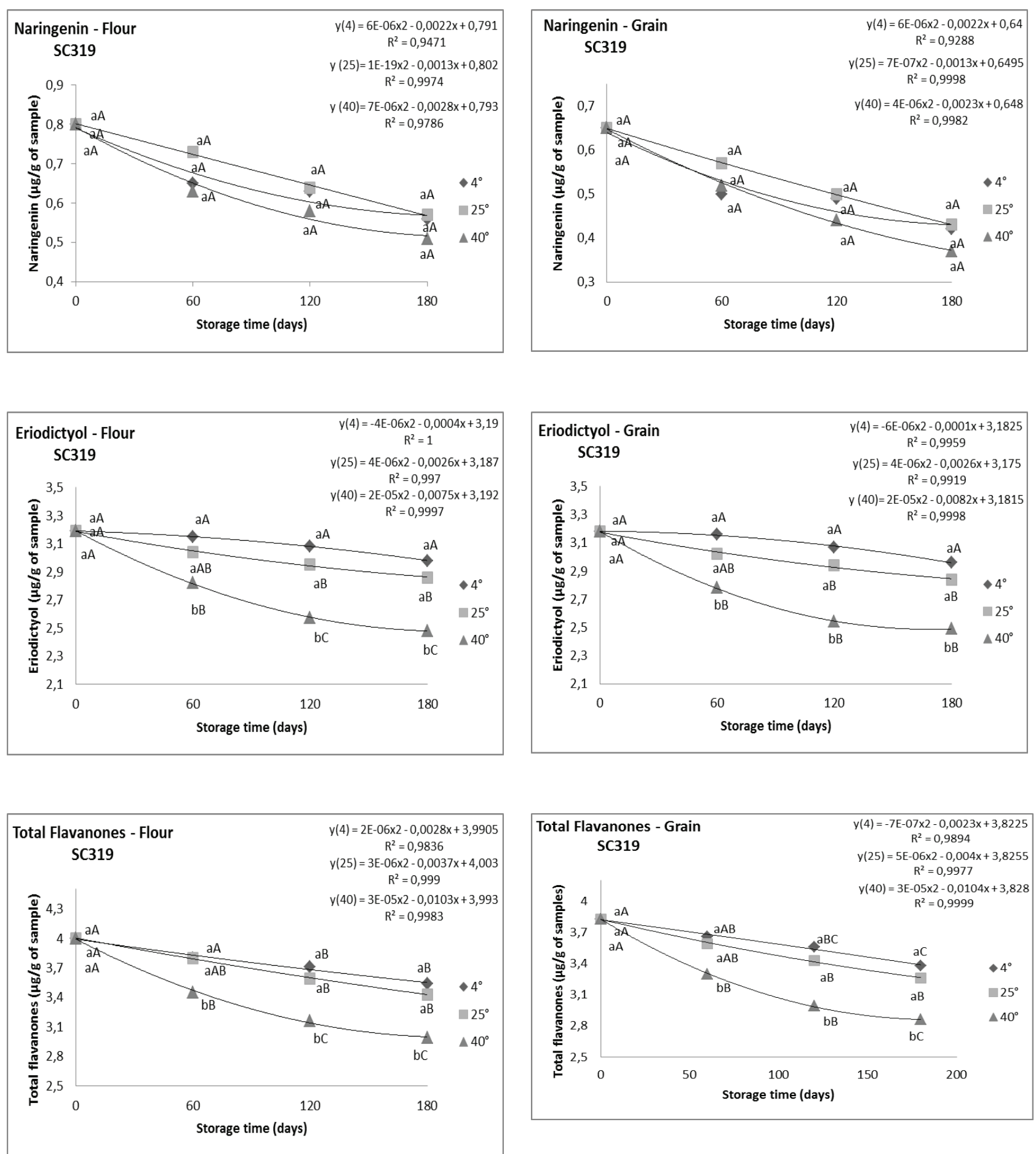

Figure 3. Flavanones contents on sorghum genotype SC319 (flour and grain) stored for 180 days under three temperatures $\left(4,25\right.$ and $\left.40^{\circ} \mathrm{C}\right)$. Results are expressed in $\mu \mathrm{g} / \mathrm{g}$ of sample on dry weight basis. Means of three replicates. Means with different lowercase letters among the temperatures and uppercase letters among the times are different by Tukey test $(\mathrm{p}<0.05)$. 

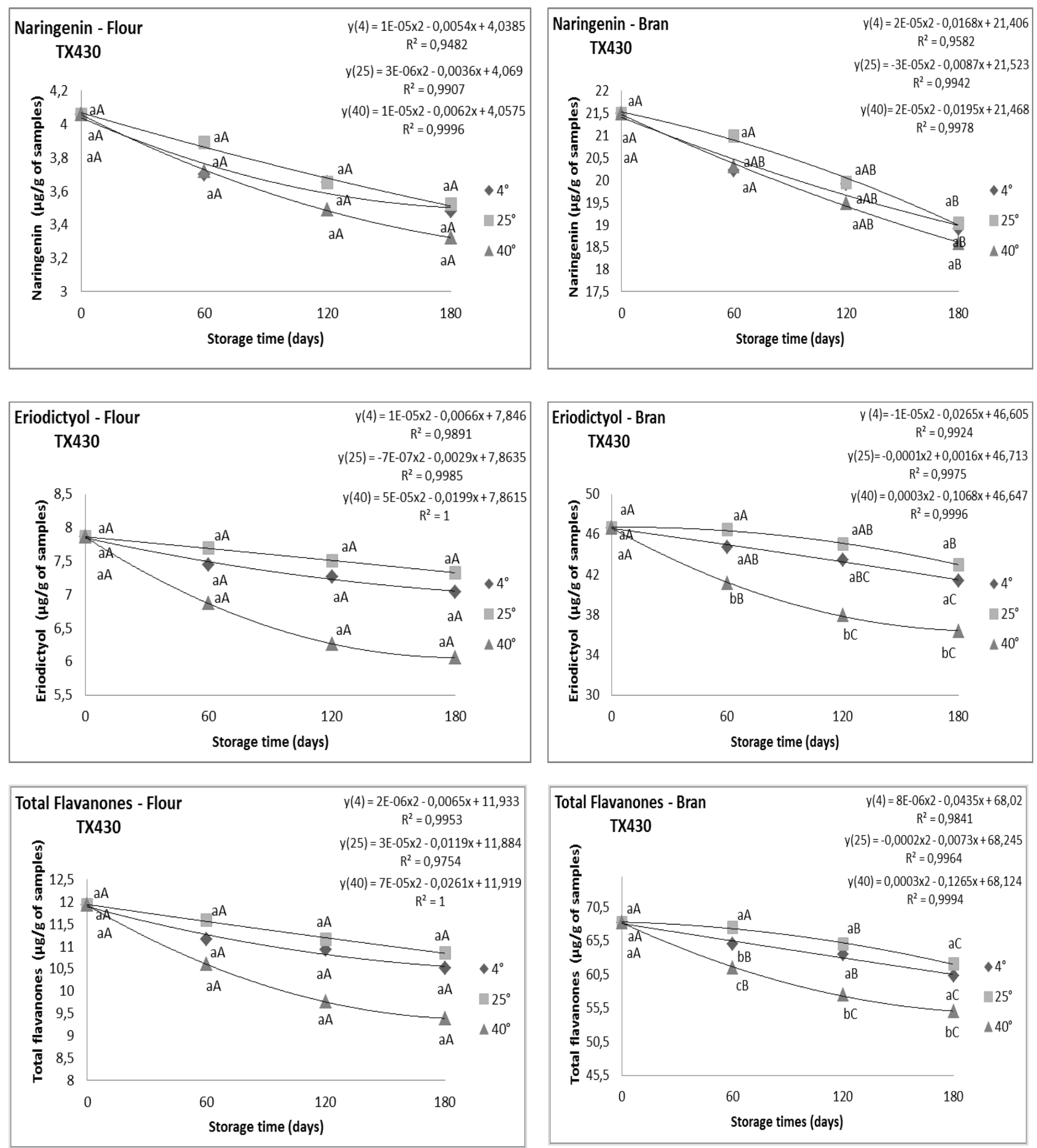

Figure 4. Flavanones contents on sorghum genotype TX430 (flour and bran) stored for 180 days under three temperatures $\left(4,25\right.$ and $\left.40{ }^{\circ} \mathrm{C}\right)$. Results are expressed in $\mu \mathrm{g} / \mathrm{g}$ of sample on dry weight basis. Means of three replicates. Means with different lowercase letters among the temperatures and uppercase letters among the times are different by Tukey test $(\mathrm{p}<0.05)$. 
storage to the $60^{\text {th }}$ day at $40^{\circ} \mathrm{C}$. After this period, the content remained stable until the end of the storage (180 days).

Therefore, storage under $4{ }^{\circ} \mathrm{C}$ was efficient to preserve the naringenin and eridioctyol contents of sorghum grain and flour of the SC 319 and flour of the TX430. However, for the sorghum bran, there was a decrease in their contents after 120 days, even at $4{ }^{\circ} \mathrm{C}$. Overall, there was no significant difference in flavanone levels between sorghum samples stored at $25{ }^{\circ} \mathrm{C}$ and $4{ }^{\circ} \mathrm{C}$.

The sum of flavanones during storage presented behavior similar to that of eriodictyol, maybe because the eriodictyol content was higher than the naringenin content.

Although there were losses in the flavone and flavanone contents, the retention percentages of these compounds were high at the end of storage, as shown in the Table 1.
For each flavonoid, means followed by different lower case letter (among storage temperatures) and by different upper case letter (among types of product) differ significantly by the Tukey test $(\mathrm{p} \leq 0.05)$.

There was no significant difference $(p>0.05)$ in the flavone and flavanone levels between flour and grain of the genotype SC319 and flour and bran of the genotype TX430 (except in the apigenin content). There was an effect of temperature on the retention rates of all analyzed compounds. The storage temperature of $4{ }^{\circ} \mathrm{C}$ was more efficient to preserve the flavone and flavanone contents in both genotypes. At this temperature, apigenin had the highest retention in the SC319 (98.75 and 99.15\%, flour and grain, respectively) and in the TX430 (96.45 and 91.22\%, flour and bran, respectively). Apigenin was followed by eriodictyol in SC319 (flour and grain: 93.42 and 93.08\%, respectively) and in TX430 (flour and bran: 89.57 and $88.69 \%$, respectively). Luteolin in SC319

Table 1. Flavones and flavanones retention (\%) on flour and grain of the genotypes SC319 and TX430 after stored for 180 days at three temperatures.

\begin{tabular}{|c|c|c|c|c|c|c|c|c|c|}
\hline \multirow[b]{2}{*}{ SC319 } & \multirow[b]{2}{*}{ Temperature } & \multicolumn{8}{|c|}{ Retention (\%) at 180 days* } \\
\hline & & \multirow{2}{*}{$\begin{array}{l}\text { Luteolin } \\
83.47 \mathrm{a}\end{array}$} & \multirow{2}{*}{$\begin{array}{l}\text { Apigenin } \\
98.75 \mathrm{a}\end{array}$} & \multicolumn{2}{|c|}{ Total Flavones } & Naringenin & Eriodictyol & \multicolumn{2}{|c|}{$\begin{array}{l}\text { Total } \\
\text { Flavanones }\end{array}$} \\
\hline \multirow{3}{*}{ FLOUR } & $4^{\circ}$ & & & 87.79 & $\mathrm{a}$ & $70.00 \mathrm{a}$ & $93.42 \quad \mathrm{a}$ & $88.50 \quad \mathrm{a}$ & \\
\hline & $25^{\circ}$ & $70.27 \mathrm{~b}$ & $95.83 \mathrm{ab}$ & 77.42 & $\mathrm{~b}$ & $71.25 \mathrm{a}$ & 89.66 & 85.75 & \\
\hline & $40^{\circ}$ & $72.50 \mathrm{~b}$ & $92.08 \mathrm{~b}$ & 78.00 & $\mathrm{~b}$ & $63.75 \mathrm{a}$ & 77.74 & 74.75 & \\
\hline \multirow{3}{*}{ GRAIN } & $4^{\circ}$ & $82.96 \mathrm{a}$ & $99.15 \mathrm{a}$ & 87.61 & $\mathrm{a}$ & $64.62 \mathrm{a}$ & 93.08 & 88.25 & \\
\hline & $25^{\circ}$ & $69.51 \mathrm{~b}$ & $95.76 \mathrm{ab}$ & 77.16 & $\mathrm{~b}$ & $66.15 \mathrm{a}$ & 89.31 & 85.12 & \\
\hline & $40^{\circ}$ & $72.23 \mathrm{~b}$ & $92.37 \mathrm{~b}$ & 78.25 & $\mathrm{~b}$ & $56.92 \mathrm{~b}$ & 78.30 & 74.67 & \\
\hline \multirow[b]{2}{*}{ TX 430} & & \multicolumn{8}{|c|}{ Retention $(\%)$ at 180 days $* *$} \\
\hline & Temperature & Luteolin & Apigenin & \multicolumn{2}{|c|}{ Total Flavones } & Naringenin & Eriodictyol & \multicolumn{2}{|c|}{$\begin{array}{l}\text { Total } \\
\text { Flavanones }\end{array}$} \\
\hline \multirow{3}{*}{ FLOUR } & $4^{\circ}$ & $87.90 \mathrm{a}$ & 96.45 aA & 89.1 & $\mathrm{a}$ & $85.71 \mathrm{a}$ & $89.57 \mathrm{a}$ & 88.17 & $\mathrm{a}$ \\
\hline & $25^{\circ}$ & $75.57 \mathrm{~b}$ & $90.65 \mathrm{abA}$ & 77.8 & $\mathrm{~b}$ & $86.70 \mathrm{a}$ & $93.26 \mathrm{a}$ & 91.02 & $\mathrm{a}$ \\
\hline & $40^{\circ}$ & $76.72 \mathrm{~b}$ & 84.19 bA & 77.8 & $\mathrm{~b}$ & $81.77 \mathrm{a}$ & $77.10 \mathrm{~b}$ & 78.69 & $\mathrm{~b}$ \\
\hline \multirow{3}{*}{ BRAN } & $4^{\circ}$ & $88.72 \mathrm{a}$ & $91.22 \mathrm{aA}$ & 88.6 & $a$ & $87.95 \mathrm{a}$ & $88.69 \mathrm{ab}$ & 88.44 & $\mathrm{a}$ \\
\hline & $25^{\circ}$ & $77.18 \mathrm{~b}$ & $79.36 \mathrm{bB}$ & 77.3 & $b$ & $88.51 \mathrm{a}$ & $92.14 \mathrm{a}$ & 90.98 & $\mathrm{a}$ \\
\hline & $40^{\circ}$ & $79.96 \mathrm{~b}$ & $69.04 \mathrm{bB}$ & 79.1 & $b$ & $86.46 \mathrm{a}$ & $77.96 \mathrm{~b}$ & 80.62 & $\mathrm{~b}$ \\
\hline
\end{tabular}

* Means of three replicates. ( $\%$ of retention from time 0 to 180 ). 
(flour and grain: 83.47 and $82.96 \%$, respectively) and in TX430 (flour and bran: 87.90 and 88.72\%, respectively). Then, naringenin in SC319 (flour and grain: 70.00 and $64.62 \%$, respectively) and in TX430 (flour and bran: 85.71 and $87.95 \%$, respectively).

There was no significant difference in the retention (\%) at 25 and $40{ }^{\circ} \mathrm{C}$, except in the case of eridioctyol for TX430, which was lower at $40{ }^{\circ} \mathrm{C}$. These results showed that the storage of sorghum flour, grain and bran for 180 days under refrigeration $\left(4{ }^{\circ} \mathrm{C}\right)$ is better to preserve the flavone and flavanone contents than room temperature $\left(25^{\circ} \mathrm{C}\right)$ or higher temperature $\left(40{ }^{\circ} \mathrm{C}\right)$.

\section{Conclusions}

The flavone and flavanone contents reduced in both sorghum genotypes during storage for 180 days. The storage temperature $\left(4{ }^{\circ} \mathrm{C}, 25{ }^{\circ} \mathrm{C}\right.$ and $40{ }^{\circ} \mathrm{C}$ ) influenced the flavones more than the flavanone contents.

Although there were losses in the flavone and flavanone content, the retention percentages of these compounds were high at the end of storage.

In general, the flavone apigenin and the flavanone eriodictyol were more stable than the flavone luteolin and the flavanone naringenin in storage at 4,25 and $40{ }^{\circ} \mathrm{C}$.

Apigenin was the most preserved compound in the flour and grain of the genotype SC319, with retentions from 92 to $99 \%$ at the end of 180 days. Naringenin presented the lowest retention (from 56.92 to $71.25 \%$ ) in the same materials.

The temperature of $4{ }^{\circ} \mathrm{C}$ was better to preserve flavones and flavanones in sorghum flour, grain and bran, with about $88 \%$ retention at the end of 180 days.

\section{Acknowledgements}

To Dr Joseph M. Awika, from Texas A\&M University (TX, USA), for the donation of the genotype TX430 samples.

\section{References}

AGCAM, E.; AKYILDIZ, A.; EVRENDILEK, G. A. Comparison of phenolic compounds of orange juice processed by Pulsed Electric Fields (PEF) and conventional thermal pasteurization. Food Chemistry, v. 143, p. 354361, 2014. DOI: 10.1016/j.foodchem.2013.07.115.

ALLOUCHE, Y.; JIMÉNEZ, A.; GAFORIO, J. J.; UCEDA, M.; BELTRÁN, G. How heating affects extra virgin olive oil quality indexes and chemical composition. Journal of Agricultural and Food Chemistry, v. 55, n. 23, p. 96469654, 2007. DOI: 10.1021/jf070628u.

AWIKA, J. M.; McDONOUGH, C. M.; ROONEY, L. W. Decorticating sorghum to concentrate healthy phytochemicals. Journal of Agricultural and Food Chemistry, v. 53, n. 16, p. 6230-6234, 2005.

DOI: $10.1021 / \mathrm{jf0510384.}$

AWIKA, J. M.; ROONEY, L. W. Sorghum phytochemicals and their potential impact on human health. Phytochemistry, v. 65, n. 9, p. 1199-1221, 2004.

DOI: 10.1016/j.phytochem.2004.04.001.

BALASUNDRAM, N.; SUNDRAMA, K.; SAMMAM, S. Phenolic compounds in plants and agri-industrial byproducts: antioxidant activity, occurrence, and potential uses. Food Chemistry, v. 99, n. 1, p. 191-203, 2006.

DOI: 10.1016/j.foodchem.2005.07.042.

CARDOSO, L. M.; MONTINI, A. T.; PINHEIRO, S. S.; PINHEIRO-SANT'ANA, H. M.; MARTINO, H. S. D.; MOREIRA, A. V. B. Effects of processing with dry heat and wet heat on the antioxidant profile of sorghum. Food Chemistry, v. 152, p. 210-217, 2014.

DOI: 10.1016/j.foodchem.2013.11.106. 
CARDOSO, L. M.; PINHEIRO, S. S.; CARVALHO, C. W. P.; QUEIROZ, V. A. V.; MENEZES, C. B.; MOREIRA, A. V. B.; BARROS, F. A. R.; AWIKA, J. M.; MARTINO, H. S. D.; SANT'ANA, H. M. P. Phenolic compounds profile in sorghum processed by extrusion cooking and dry heat in a conventional oven. Journal of Cereal Science, v. 65, p. 220-226, 2015. DOI: 10.1016/j.jcs.2015.06.015.

DYKES, L.; PETERSON, G. C.; ROONEY, W. L.; ROONEY, L. W. Flavonoid composition of lemon-yellow sorghum genotypes. Food Chemistry, v. 128, n. 1, p. 173179, 2011. DOI: 10.1016/j.foodchem.2011.03.020.

DYKES, L.; ROONEY, L. W. Sorghum and millet phenols and antioxidants. Journal of Cereal Science, v. 44, n. 3, p. 236-251, 2006. DOI: 10.1016/j.jcs.2006.06.007.

DYKES, L.; SEITZ, L. M.; ROONEY, W. L.; ROONEY, L. W. Flavonoid composition of red sorghum genotypes. Food Chemistry, v. 116, n. 1, p. 313-317, 2009.

DOI: https://doi.org/10.1016/j.foodchem.2009.02.052.

HOUNSOME, N.; HOUNSOME, B.; TOMOS, D.; EDWARDS-JONES, G. Changes in antioxidant compounds in white cabbage during winter storage. Postharvest Biology and Technology, v. 52, n. 2, p. 173-179, 2009. DOI: 10.1016/j.postharvbio.2008.11.004.

IOANNOU, I.; HAFSA, I.; HAMDI, S.; CHARBONNEL, C.; GHOUL, M. Review of the effects of food processing and formulation on flavonol and anthocyanin behaviour. Journal of Food Engineering, v. 111, n. 2, p. 208-217, 2012. DOI: 10.1016/j.jfoodeng.2012.02.006.

KADIVEC, M.; BORNŠEK, S. M.; POLAK, T.; DEMŠAR, L.; HRIBAR, J.; POŽRL, T. Phenolic content of strawberry spreads during processing and storage. Journal of Agricultural and Food Chemistry, v. 61, n. 38, p. 9220-9229, 2013. DOI: 10.1021/jf4035767.

KHAN, M. K.; DANGLES, O. A comprehensive review on flavanones, the major citrus polyphenols. Journal of Food Composition and Analysis, v. 33, n. 1, p. 85104, 2014.

DOI: 10.1016/j.jfca.2013.11.004.
LIU, W.; ZU, Y. G.; FU, Y. J.; KONG, Y.; MA, W.; YANG, M.; WU, N. Variation in contents of phenolic compounds during growth and post-harvest storage of pigeon pea seedlings. Food Chemistry, v. 121, n. 3, p. 732-739, 2010. DOI: 10.1016/j.foodchem.2010.01.023.

LOZANO-SÁNCHEZ, J.; BENDINI, A.; QUIRANTESPINÉ, R.; CERRETANI, L.; SEGURA-CARRETERO, A.; FERNÁNDEZ-GUTIÉRREZ, A. Monitoring the bioactive compounds status of extra-virgin olive oil and storage byproducts over the shelf life. Food Control, v. 30, n. 2, p. 606-615, 2013.

DOI: 10.1016/j.foodcont.2012.06.036.

MORAES, E. A.; MARINELLI, R. S.; LENQUISTE, S. A.; STEEL, C. J.; MENEZES, C. B.; QUEIROZ, V. A. V.; MARÓSTICA JÚNIOR, M. R. Sorghum flour fractions: correlations among polysaccharides, phenolic compounds, antioxidant activity and glycemic index. Food Chemistry, v. 180, p. 116-123, 2015.

DOI: 10.1016/j.foodchem.2015.02.023.

MORAES, E. A.; NATAL, D. I. G.; QUEIROZ, V. A. V.; SCHAFFERT, R. E.; CECON, P. R.; PAULA, S. O. de; BENJAMIM, L. A.; RIBEIRO, S. M. R.; MARTINO, H. S. D. Sorghum genotype may reduce low-grade inflammatory response end oxidative stress and maintains jejunum morphology of rats fed a hyperlipidic diet. Food Research International, v. 49, n. 1, p. 553559, 2012.

DOI: 10.1016/j.foodres.2012.07.029.

OLIVEIRA, K. G.; QUEIROZ, V. A. V.; CARLOS, L. de A.; CARDOSO, L. de M.; PINHEIRO-SANT'ANA, H. M.; ANUNCIAÇÃO, P. C.; MENEZES, C. B.; SILVA, E. C. da; BARROS, F. Effect of the storage time and temperature on phenolic compounds of sorghum grain and flour. Food Chemistry, v. 216, p. 390-398, 2017.

DOI: $10.1016 /$ j.foodchem.2016.08.047.

PAIVA, C. L.; QUEIROZ, V. A. V.; SIMEONE, M. L. F.; SCHAFFERT, R. E.; OLIVEIRA, A. C.; SILVA, C. S. da. Mineral contents in sorghum genotypes: influence of water stress. Food Chemistry, v. 214, p. 400-405, 2017.

DOI: 10.1016/j.foodchem.2016.07.067. 
PLAZA, L.; CRESPO, I.; DE PASCUAL-TERESA, S.; DE ANCOS, B.; SÁNCHEZ-MORENO, C.; MUÑOZ, M.; CANO, M. P. Impact of minimal processing on orange bioactive compounds during refrigerated storage. Food Chemistry, v. 124, n. 2, p. 646-651, 2011.

DOI: 10.1016/j.foodchem.2010.06.089.

QUEIROZ, V. A. V.; SILVA, C. S.; MENEZES, C. B.; SCHAFFERT, R. E.; GUIMARÃES, F. F. M.; GUIMARÃES, L. J. M.; GUIMARÃES, P. E. O.; TARDIN, F. D. Nutritional composition of [Sorghum bicolor (L.) Moench] genotypes cultivated without and with water stress. Journal of Cereal Science, v. 65, p. 103-111, 2015. DOI: 10.1016/j.jcs.2015.06.018.

RAVISHANKAR, D.; CORONA, G.; HOGAN, S. M.; SPENCER, J. P.; GRECO, F.; OSBORN, H. M. Thioflavones as novel neuroprotective agents. Bioorganic
\& Medicinal Chemistry, v. 24, n. 21, p. 5513-5520, 2016. DOI: 10.1016/j.bmc.2016.09.006.

SINGH, M.; KAUR, M.; SILAKARI, O. Flavones: an important scaffold for medicinal chemistry. European Journal of Medicinal Chemistry, v. 84, p. 206-239, 2014. DOI: 10.1016/j.ejmech.2014.07.013.

YANG, L.; ALLRED, K. F.; GEERA, B.; ALLRED, C. D.; AWIKA, J. M. Sorghum phenolics demonstrate estrogenic action and Induce apoptosis in nonmalignant colonocytes. Nutrition and Cancer, v. 64, n. 3, p. 419-427, 2012.

DOI: $10.1080 / 01635581.2012 .657333$.

VERMA, A. K.; PRATAP, R. Chemistry of biologically important flavones. Tetrahedron, v. 68, n. 41, p. 85238538, 2012.

DOI: $10.1016 /$ j.tet.2012.06.097. 